\title{
Challenges of devolved health care in Kenya: an analysis of the policy and legislative framework
}

\author{
by Naomi GICHUKI*
}

\begin{abstract}
This paper comes in the wake of the COVID-19 Pandemic. A pandemic that not only ground the world to a halt, but one that also forced governments and stakeholders alike to critically evaluate the health sector. Inherent challenges plaguing the sector have been emphasized, and latent challenges brought to the surface. In Kenya, health is the largest devolved function of government, thanks to the Constitution of 2010, which devolved administrative and other governance functions to the 47 counties. Through what should have been a transitional period until now, devolution continues to present diverse administrative and governance challenges across the board, and the health sector, like many others, has not been spared. This paper examines the concept of health in light of public health and as a fundamental human right. This is followed by an examination of the policy and legislative framework that informs, guides, governs and regulates the health sector in Kenya as well as an exposition of the core challenges affecting the health sector. Recommendations and further areas of research form the conclusion of this paper.
\end{abstract}

\section{A. INTRODUCTION}

The World Health Organisation (WHO) defines health as

'a state of complete physical, mental and social well-being and not merely, the absence of disease and infirmity.'

From the foregoing, it is evident that healthcare requires an examination that is holistic in its approach. The all-inclusive definition advanced by the WHO suggests that healthcare affects every facet of human existence, including not only the population in terms of the clinical health of people, but also the state of the physical environment in which people live and go about their daily lives.

In this regard therefore, the sector may be examined from two main perspectives - that of public health and of health as a fundamental human right. It also calls for an analysis of the structures and actors responsible for delivery of public health services as well as a brief overview of the core aspects and rationale for public health in addition to a more detailed

* The Author is a Legal Consultant and Advocate of the High Court of Kenya with a keen interest in Public Governance, Rule of Law and Governance of the Extractives Sector (Mining, Oil and Gas). Ms. Gichuki can be reached through gichukinyambura@gmail.com. 
exposition of the essential elements of the right to health as provided both by domestic law and by the International Conventions and Treaties to which Kenya is a signatory.

\section{Public Health}

As a field and area of practice, public health is a significant component in the well-being of any society and lends itself to covering a broad range in terms of the variety and abundance of subjects that concern it. From traditional medical care to more elaborate subjects such as population, mental health, maternal and child health, medical/health law, water and occupational health and safety. ${ }^{1}$ The main difference between public health and clinical professions is in relation to the strategies employed, with public health being anchored on social justice, and the premise that all people are deserving of healthy conditions in which to live, regardless of their status or stature in society. ${ }^{2}$

Public health therefore plays an integral and leading role in ensuring that the obligation to create a healthy populace is carried out effectively. The preferred approach adopted in public health is that of prevention, which requires addressing the conditions in which people live. As a result, the definitive strategy for public health is to prevent poor health by 'assuring conditions in which people can be healthy' whereas the approach adopted by clinical professions is to restore health or otherwise prevent the worsening of existing health problems. ${ }^{3}$ Public health is a public matter mainly concerned with advocacy and serviceprovision that is geared towards assisting the structurally disadvantages courtesy of their social circumstances. ${ }^{4}$

Like every public function, organizational structure and funding plays a central role. Public health is no exception, extending beyond government and embracing the efforts, science, art and methods used by various actors in a society in order to assure, maintain, protect, promote and improve the health of the people. This confirms the reality of the inability of governments to solely provide the full range of essential services pertaining to health, even though it plays a frontline role in the public health system, As a consequence, local communities, health care delivery structures, employers and businesses in the private sector, media, academia and government all constitute the core actors whose role and position greatly affects health. ${ }^{5}$

Public health systems are defined as all public, private and voluntary entities that contribute to the delivery of essential public health services within a jurisdiction. ${ }^{6}$ These systems comprise a network of entities with different roles, relationships and interactions,

1 Raymond L. Goldsteen, Karen Goldsteen \& David Graham. Introduction to Public Health. Springer Publishing Company, 2011. P 1-3.

2 Ibid, at p.11.

3 Ibid, at p.6.

4 Ibid, at p.11.

5 Ibid, at p.71.

6 R.Goldsteen, et al, at p.74. 
collectively aimed at securing the health and well-being of the State of community. ${ }^{7}$ Even though public health requires the synergized efforts of various stakeholders as described earlier, government agencies form the backbone of the public health system and have the unique legal mandate and resource capacity to design and implement health policies as well as enforce laws and secure the rights antecedent to the enjoyment and fulfillment of the right to health. ${ }^{8}$

\section{The Right to Health}

The right to health is a fundamental human right, the realization of which in addition to requiring the action of diverse stakeholders, also calls for the adoption of diverse and complementary approaches including formulation of suitably-tailored health policies, adoption of legal instruments and implementation of WHO-designed programs. ${ }^{9}$ In full, the right to health in full is 'the right to the enjoyment of the highest attainable standard of physical and mental health. ${ }^{\prime 10}$ The right to health is closely connected to, intertwined with and dependent on the realization of other human rights, in addition to being dependent on the conditions prevailing in a State at any given time.

On the international level, the right to health is guaranteed in several international instruments. In the Universal Declaration on Human Rights (UDHR), ${ }^{11}$ The International Covenant on Economic Social and Cultural Rights (ICESCR) provides what is described as the most comprehensive articulation on the Right to Health. Other international treaties that provide for the Right to Health include the Convention on All Forms of Discrimination Against Women (CEDAW), the Convention on the Rights of the Child (CRC) and the African Charter on Human and People's Rights (Banjul Charter).

Being an inclusive right, the Right to Health requires what are termed as 'underlying determinants of health' in order for individuals to enjoy a healthy life. These factors include safe drinking water and sanitation, adequate nutrition and housing, safe food, healthy working conditions, a healthy environment, gender equality and health-related education and information. ${ }^{12}$ In addition to underlying determinants of health, the right to health also contains other entitlements including; the right to a system of health protection providing equality of opportunity for everyone to enjoy the highest attainable standard of health; access to essential medicines; maternal, child and reproductive health; the right to prevention,

7 Ibid, at p.71.

8 Ibid, at p.74.

9 CESCR General Comment No.14: The Right to Highest Attainable Standard of Health (Adopted on $11^{\text {th }}$ August, 200).

10 OHCHR \& WHO. The Right to Health. Office of the United Nations High Commissioner for Human Rights \& the World Health Organisation. Factsheet No. 31. At p.1.

11 Article 25.

12 OHCHR. The Right to Health. (Factsheet No. 13). Office of the United Nations Commissioner for Human Rights \& the World Health Organisation. At p. 3. 
treatment and control of disease; equal and timely access to basic health services; community participation in health decision-making at national and other levels of governance as well as the provision of health-related education and information. ${ }^{13}$

Equality also features strongly in relation to enjoyment of the Right to Health. As such, it is required and expected that the provision of health-related services, facilities and goods must be delivered to all people without discrimination. ${ }^{14}$ Health services and facilities must also be available, accessible and appropriate. Availability requires that health services and facilities by obtainable in quantities that are sufficient. Accessibility on the other hand, relates both to physical accessibility as well as financial accessibility, so that regardless of one's status in society, an individual should be able to access health facilities literally, and should have the same provided in a manner that is not financially prohibitive. Health services and facilities are considered appropriate when they fulfil the requisite scientific and medical standards. This calls for scientifically approved and unexpired drugs and equipment, trained medical personnel, safe drinking water and adequate sanitation. ${ }^{15}$

The nature of the Right to Health makes it a right that is subject to progressive realization. States are therefore under the obligation to formulate legislation, policies and plans that ensure a minimum basic level of access to the essential components of the Right to Health. As such, the measures and steps taken by States will vary from one country to another, based on the prevailing political and development contexts of the State in question. That notwithstanding, States are generally prohibited from blaming the absence of resources for their failure to respect and uphold their obligations as far the Right to Health is concerned. Active steps to respect, protect, and fulfil the Right to Health must be taken by ever State.

In addition to having policies, laws and plans for health care, national health systems ought to meet a minimum threshold which includes; an adequate system for the collection of health data to monitor the realization of the right to health; sufficiently disaggregated data that captures core demographic details of the people seeking health services; the capacity to produce a sufficient number of well-trained health workers who work in favourable work environments; impact assessment processes before finalizing major policies that are healthrelated; frameworks that permit public participation in the formulation of health policies and effective, transparent and accessible mechanism of accountability. ${ }^{16}$

States are also required, in exercise of good governance, to have in place, accessible, transparent and effective accountability mechanisms. By so doing, States not only explain what they are doing to realise the right to health, but also make known the methods and justifications of the various strategies, actions and measures taken in an attempt to ensure the Right to Health is fully realized. Accountability mechanisms at national level can be di-

\section{Ibid.}

14 Ibid.

15 Ibid, at p.4.

16 OCHCR. The Right to Health. At p. 27. 
vided into three main categories; Administrative, policy and political mechanisms which focus on the development of policies, impact assessments, the use of Human Rights Based indicators to monitor key outcomes and review of policy, budgets and governmental monitoring. The second category entails judicial mechanisms, which basically guarantees the provision of remedies for violations of the Right to Health, hearing cases related to health and incorporating international instruments in domestic laws. ${ }^{17}$ The final accountability mechanism is through the use of National Human Rights Institutions, which play crucial roles in advising the government and recommending policy or legislative changes, handling complaints and carrying out investigations as well as providing training and civic education. ${ }^{18}$

\section{State Obligations in Relation to the Right to Health}

The ICESCR provides for the progressive realization of rights, certain obligations requiring immediate effect are placed on States. Among these is the obligation to take deliberate, concrete and targeted steps aimed at the full realization of the right to health. ${ }^{19}$ As with other human rights, there are three main levels of obligations on States namely, to respect, to protect and to fulfil. The obligation to respect involves States not interfering, whether directly or otherwise with the enjoyment of the Right to Health. The obligation to protect mandates the State to actively take measures preventing third parties with interfering with the enjoyment of the Right to Health. The obligation to fulfil requires that States ought to take on appropriate legislative, administrative, budgetary and judicial measures towards the full realization of the Right to Health. ${ }^{20}$

\section{State Obligations During Pandemics}

In addition to States having an obligation to ensure minimum levels of the Right to Health, States also have core obligations as far as taking measures to prevent, treat and control epidemic and endemic diseases. ${ }^{21}$ The prevention, treatment and control of epidemic, endemic and other diseases requires establishment of prevention and education programs for behavior related health concerns..$^{22}$ In this regard, control of diseases refers to efforts taken by States individually and collectively to avail relevant technologies, to use and improve epidemiological surveillance, data collection, and to implement or enhance immunization pro-

17 Ibid, at. P 31-33.

$18 \mathrm{Ibid}$, at p. 34.

19 CESCR General Comment No. 13, para 43 as cited in CESCR General Comment No. 14: The Right to the Highest Attainable Standard of Health. Adopted on $11^{\text {th }}$ August 2000.

20 CESCR. General Comment No. 14: The Right to the Highest Attainable Standard of Health, p. 11 para 33.

21 Ibid, p.16 para 44 (c).

22 Ibid, p. 6 para 16. See also ICESCR Art. 12.2 (c). 
grams and other strategies suitable for the control of infectious diseases. ${ }^{23}$ The right to treatment calls for creation of systems that deliver urgent medical care and the provision of disaster relief and humanitarian assistance in emergency situations. ${ }^{24}$

In the wake of the COVID-19 pandemic, the World Health Organisation was at the forefront of developing and disseminating measures aimed at containing and controlling the spread of COVID-19. In Kenya, containment measures included the closure of all schools and institutions of higher learning, the closure of churches, mosques and places of worship, closure of restaurants, bars, night clubs and places of entertainment, a nation-wide curfew that was revised over a series of months from the onset of the first confirmed case in March 2020 until the time of writing this article in November 2020, mandatory social distancing in public places, banning of social gatherings exceeding 15 people, banning of weddings (later revised to ceremonies accommodating not more than 100 people), lockdowns of towns that were considered epicenters of the disease, mandatory wearing of masks in public places, mandatory installation of hand-washing stations in public areas and business premises, work-from-home directives for all activities that were not officially gazette as essential services.

\section{B. GOVERNANCE STRUCTURES \& THE RIGHT TO HEALTH IN KENYA}

The provision of health care services and realization of the Right to Health cannot be entirely divorced or separated from the governance structures in place within a given jurisdiction. This is because governments have the unique responsibility to promote public health. In addition, the legal authority and resources to implement health-related policy, pass laws and regulate delivery of healthcare services is vested in the government. ${ }^{25}$ As such, good governance in this context requires directing health system resources, performance and stakeholder participation toward the goals of saving lives, and doing so in was that are open, transparent, accountable, equitable and responsive to the needs of the people. ${ }^{26}$

The Republic of Kenya is a Unitary States, divided into 47 Counties on the basis of devolved government as established under the Constitution. ${ }^{27}$ Devolution is one of the national values and principles of governance ${ }^{28}$ and is defined as the distribution of state functions and powers between the three arms of government. ${ }^{29}$ Devolution may also be defines

25 R. Goldsteen, Op Cit at p. 74.

26 Mulaki, A. \& S. Muchiri. Kenya Health System Assessment. Palladium, Health Policy Plus. Washington DC. 2019 At p. 15.

27 Art. 1(3) \& (4); Art. 6(1) \& (2); Art. 10; Chapter 11 and Schedules $1 \& 4$ - Constitution of Kenya, 2010.

28 Ibid, Art. 10.

29 Friedrich Ebert Stiftung. Devolution System Made Simple. A Popular Version of County Governance System. Friedrich Ebert Stiftung. November, 2012. 
as a form of decentralization founded on the principle of subsidiarity, and aims at promoting individual freedom and public participation in governance. ${ }^{30}$ Devolution involves restructuring and re-organizing authority so that a system of co-responsibility between institutions of governance is established across the various levels of government according to the principle of subsidiarity. ${ }^{31}$

Constitutionally, devolution has several objectives, including; promoting democratic and accountable exercise of power; ${ }^{32}$ giving powers of self-governance to the people and enhancing the participation of the people in the exercise of powers of the state and in making decisions affecting them; ${ }^{33}$ promoting the provision of proximate, easily accessible services throughout Kenya ${ }^{34}$ and facilitating the decentralization of State organs, functions and services. ${ }^{35}$

Government at the national and county levels are distinct and inter-dependent, and required to conduct their mutual relations on the basis of consultation and cooperation. ${ }^{36}$ The County Governments in Kenya have two arms, being the Executive and Legislative arms. The Judicial arm is a shared institution, with operations within the various established counties. County governments established under the Constitution are based on democratic principles and the separation of powers; ${ }^{37}$ are expected to have reliable sources of revenue to enable them to govern and deliver services effectively; ${ }^{38}$ and should have no more than two thirds of the members of representative bodies in the county government being of the same gender. ${ }^{39}$

The Legislature passed several pieces of legislation to guide the implementation of devolution. Including the Transition to Devolved Government Act, ${ }^{40}$ County Governments Act ${ }^{41}$ the Intergovernmental Relations Act, ${ }^{42}$ the Leadership \& Integrity $\mathrm{Act}^{43}$ and the Public Finance Management Act among ${ }^{44}$ others. Generally, counties have a huge responsibility as far as service delivery is concerned, and as such are empowered by law to; discharge

30 Onesimus K. Murkomen. Devolution and the Health System in Kenya. USAID: Health Policy Project.

31 Ibid.

32 Art. 174(a).

33 Art. 174(c).

34 Art. 174(f).

35 Art. 174(h).

36 The Constitution of Kenya, 2010. Art. 6(2).

37 Ibid, Art. 175 (a)

38 Ibid, Art. 175 (b)

39 Ibid, Art. 175 (c).

40 Act No. 1 of 2012.

41 Act No. 17 of 2012.

42 Act No. 2 of 2012.

43 Act No. 19 of 2012.

44 Act No. 18 of 2012. 
their functions; ${ }^{45}$ establish agencies ${ }^{46}$ and Private-Public Partnerships; ${ }^{47}$ enter into contracts; ${ }^{48}$ employ staff; ${ }^{49}$ delegate any functions to its officers, decentralized units and other entities ${ }^{50}$ as well as to acquire, purchase and lease land ${ }^{51}$ Like the National Government, the County Governments are permitted to; secure resources; have democratically elected representatives and autonomous political authority; deliver services ${ }^{52}$ and make and enforce legislation. ${ }^{53}$

\section{LEGISLATIVE \& POLICY FRAMEWORK GOVERNING HEALTH IN KENYA}

\section{The Constitution of Kenya, 2010}

The Constitution of Kenya remains the primary legislative instrument that establishes the foundation for the Right to Health, ${ }^{54}$ as well as the parameters of shared responsibility and cooperation between the national and county governments with regard to delivery of healthcare services in the country. ${ }^{55}$ Constitutionally, the Bill of Rights applies to all law and binds all State organs and persons in Kenya. ${ }^{56}$ Every person therefore, is entitled to enjoy the rights and fundamental freedoms in the Bill of Rights to the greatest extent consistent with the nature of the right or fundamental freedom. ${ }^{57}$ In addition, the State and all its organs are duty bound to observe, respect, protect, promote and fulfil the rights and fundamental freedoms in the Bill of Rights. ${ }^{58}$

As set out earlier in this paper, the Right to Health is an interdependent right that requires the realization of other antecedent rights. In Kenya, every person has the right to the highest attainable standard of health, which includes the right to health care services, including reproductive health care ${ }^{59}$ reasonable standards of sanitation; ${ }^{60}$ freedom from hunger

45 The County Governments Act, No. 17 of 2012. S. 6(1).

46 Ibid, S. 6(5).

47 Ibid, S. 6(3).

48 Ibid, S. 6(2)(a).

49 Ibid, S. 5(f).

50 Ibid, S. 6(2)(c).

51 Ibid, S. 6(2)(b).

52 The County Governments Act, No. 17 of 2012. S. 116(1).

53 Ibid, S. 5(a).

54 Chapter Four - The Bill of Rights.

55 Art. 189-191.

56 Art. 20(1).

57 Art. 20(2).

58 Art. 21(1).

59 Art. 43(1)(a).

60 Art. 43(1)(b). 
and the right to adequate food of acceptable quality; ${ }^{61}$ clean and safe water in adequate quantities; ${ }^{62}$ social security ${ }^{63}$ and education. ${ }^{64}$ Further, no person is to be denied emergency medical treatment. ${ }^{65}$ Further, the Constitution provides that every person has the right to life, ${ }^{66}$ and the right to a clean and healthy environment. ${ }^{67}$

The State is required to put in place affirmative action programs designed to ensure that minorities and marginalized groups have reasonable access to water, health services and infrastructure. ${ }^{68}$ The State is also bound to take legislative, policy and other measures including the setting of standards, to achieve the progressive realization of the right to health. ${ }^{69}$ In relation to distribution of functions pertaining to healthcare, the National Government is tasked with health policy ${ }^{70}$ and capacity building and technical assistance to the counties. ${ }^{71}$ The County Governments are tasked with county health services ${ }^{72}$ including; county health facilities and pharmacies, ambulance services, promotion of primary health care, licensing and control of undertakings that sell food to the public, veterinary services (excluding regulation of the profession), cemeteries and the removal of refuse, managing refuse dumps and disposal of solid waste. ${ }^{73}$

\section{The County Governments Act, No. 17 of 2012}

The County Governments Act is one of several Acts passed by the National Assembly to actualize devolved governance in Kenya. The Act provides for county governments' powers, functions and responsibilities to deliver services and for connected purposes. The Act sets out the principles ${ }^{74}$ and objectives ${ }^{75}$ of planning and development facilitation at the county level. The Act also establishes the framework for integration of national and county planning, ${ }^{76}$ providing that cooperation in planning is to be undertaken in the context of the

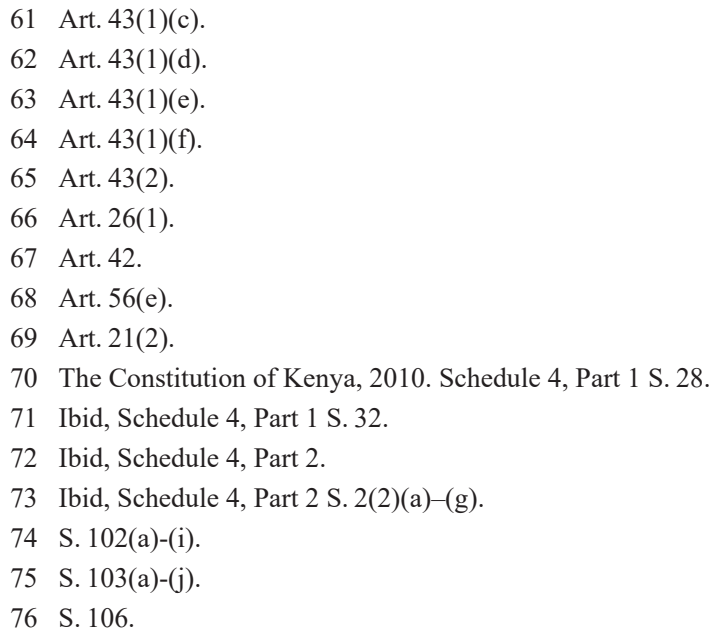


law governing inter-governmental relations. ${ }^{77}$ Further, county plans must be based on the functions of the county governments as specified in the Fourth Schedule to the Constitution and on relevant national policies, ${ }^{78}$ and must take cognizance of the financial viability of development programs ${ }^{79}$ and provide for citizen participation. ${ }^{80}$

\section{The Health Act, No. 21 of 2017}

This Act establishes a unified health system, to coordinate the inter-relationship between the national government and county government health systems, to provide for the regulation of health care service and health care service providers, health products and health technologies and for connected purposes. The Act establishes the various administrative structures and their respective functions at both the National and County levels.

As far as responsibility is concerned, the State is tasked with; developing law and policy; ${ }^{81}$ prioritizing adequate investment in research ${ }^{82}$ ensuring realization of health related rights and interests of vulnerable groups ${ }^{83}$ and ensuring provision of health care at all levels of the health care system. ${ }^{84}$ The Ministry of Health of the National Government has 26 core functions under the Act, including developing health policies, laws, and administrative procedures and programs; ${ }^{85}$ ensuring implementation of rights to health specified in the Bill of Rights; ${ }^{86}$ consultation and collaboration with stakeholders; ${ }^{87}$ offering technical support in strengthening the health system ${ }^{88}$ and coordinating the development of standards for quality health care service delivery. ${ }^{89}$

County Governments are responsible for; implementing the national health policy; ${ }^{90}$ service delivery $;^{91}$ coordinating health services to ensure complementary inputs, avoid duplication and provide cross-referral where necessary to and from institutions in other counties; ${ }^{92}$ facilitating registration, licensing and accreditation of providers and health facili-

77 S. 106(1).

78 S. 106(2).

79 S. 106(3).

80 S. 106(4).

81 S. 4(a).

82 S. 4(b).

83 S. 4(c).

84 S. 4(d).

85 S. $15(1)(a)$.

86 S. 15(1)(c).

87 S. 15(1)(d).

88 S. $15(1)(\mathrm{e})$.

89 S. $15(1)(\mathrm{m})$.

90 S. 20(a).

91 S. 20(b).

92 S. 20(c). 
ties $;{ }^{93}$ designation of count referral hospitals $;{ }^{94}$ developing and implementing such policies as may be necessary to guarantee the staffing of the public health service ${ }^{95}$ as well as procuring and managing health services, ${ }^{96}$ amongst several other functions. ${ }^{97}$

The Act establishes a County Executive Department responsible for health which shall in all matters be answerable to the Governor and the County Assembly ${ }^{98}$ as well as the office of the County Director of Health, who shall be a technical advisor on all matters of health in the County; ${ }^{99}$ be the technical advisor to the County Health Executive Committee member and the Governor ${ }^{100}$ and among other tasks, ${ }^{101}$ supervise all health services within the county. ${ }^{102}$

The rights of healthcare providers shall include the right not to be unfairly discriminated against on account of any of the grounds set out in the Constitution, ${ }^{103}$ the right to a safe working environment ${ }^{104}$ and the right to apply for and accept salaried posts in the public service or the private sector. ${ }^{105}$ Healthcare providers are duty bound to; provide health care, conscientiously and to the best of their knowledge and skill; ${ }^{106}$ provide emergency medical treatment ${ }^{107}$ and to inform users of the health system, of their health status in a manner commensurate with the user's understanding. ${ }^{108}$ The Act also sets out various duties which users of the health system are expected to fulfil. ${ }^{109}$

In addition to rights, duties and obligations, the Act requires the respective levels of government and other agencies to collaborate, consult and enter into agreements for the better carrying out of the provisions of the Act. ${ }^{110}$ Specifically, there are seven core fields in which collaboration, consultation and cooperation in this regard is required. These are;

93 S. 20(d).

94 S. 20(e).

95 S. 20(f).

96 S. $20(\mathrm{~g})$.

97 S. 20(h)-(p).

98 S. 19(1).

99 S. 19(2).

100 S. 19(5)(b).

101 S. 19(5)(d)-(g).

102 S. 19(5)(c).

103 S. 12(1)(a).

104 S. 12(1)(b).

105 S. 12(1)(d).

106 S. 12(2)(a).

107 S. 12(2)(b).

108 S. 12(2)(c).

109 S. 13(a)-(f).

110 S. 106(1). 
health workers' welfare; ${ }^{111}$ health aspects of environmental protection; ${ }^{112}$ issues of animal health; ${ }^{113}$ professional education and training; public education; ${ }^{114}$ financing of health services; ${ }^{115}$ and bio-medical services. ${ }^{116}$ In addition, private and public health services are required to complement each other in the provision of comprehensive and accessible health care to people 117

\section{Kenya Health Policy 2014-2030}

The Kenya Health Policy (hereafter referred to as the Policy), was developed through a participatory process that brought together major stakeholders in the health sector including the government and its agencies, clients, county governments, multilateral and bilateral development partners as well as various implementing partners including faith-based organizations, the private sector and civil society. ${ }^{118}$ The policy forms the fundamental framework for managing the devolution of the healthcare sector, through and beyond the transition period. In addition to focusing on the realization of the right to health and contributing to the economic development of Kenya as envisioned in Vision 20230, the policy provides for the strengthening of the necessary national, county and intergovernmental mechanisms and frameworks within which health is to be managed as a devolved function.

The key objectives of the policy include; elimination of communicable conditions and diseases; halting and reversing the rising burden of non-communicable conditions; reducing the burden of violence and injuries; providing essential healthcare; minimizing exposure of health risk factors and strengthening collaboration with private and other health-related sectors. ${ }^{119}$ The goal of the Policy is the attainment of the highest standard of health in a manner responsive to the needs of the Kenyan population. As such, the Policy defines priority reforms as well as flagship projects and programs including the restructuring of leadership and governance in the sector, improving procurement and increasing availability essential health products and technologies. ${ }^{120}$ Closely connected projects also include digitization of records and health information system, acceleration of the process of equipping of health facilities, human resource development and initiating mechanisms towards universal health coverage. $^{121}$

111 S. 108(a).

112 S. $108(\mathrm{~b})$.

113 S. 108(c).

114 S. 108(d).

115 S. $108(\mathrm{e})$.

116 S. $108(\mathrm{f})$.

117 S. 88(2).

118 Foreword to the Kenya Health Policy 2014-2030.

119 Kenya Health Policy (2014-2030) at p. 4.

$120 \mathrm{Ibid}$, at p. 5 .

121 Ibid. 
The Policy formulates specific principles and orientations to facilitate the development of comprehensive health investments, health plans and service provision within the devolved healthcare system. In addition to those set out in Art. 10 and 232 of the Constitution, the health sector specifically adopts the principles of public participation, efficiency in application of health technologies and mutual consultation and cooperation between the national and county governments and among county governments as its guiding principles. ${ }^{122}$

The policy orientations are listed as health financing; leadership; health products and technologies; health information; health workforce; service delivery systems; health infrastructure and research and development. ${ }^{123}$ It is these orientations that constitute the policy's key action areas and define the health sector's intent as far as making investments that will facilitate attainment of the policy objectives. Effectiveness is to be measured in terms of improvement in health outputs, access to healthcare, quality of healthcare and demand for healthcare. It is worth noting that the policy objectives and orientations are not mutually exclusive and are to be addressed from a collaborative viewpoint.

\section{SITUATIONAL ANALYSIS OF MAJOR CHALLENGES IN KENYA'S HEALTH SECTOR}

The health sector was the largest service sector to be devolved under the new governance structure set out in the Constitution of 2010. The rationale for this was to enable the county governments to design models and interventions that were innovative and best suited to the unique health needs of their regions, create platforms for citizen engagement in decision making and to enable county governments make independent and timely decisions pertaining to resource mobilization and management in their respective jurisdictions. ${ }^{124}$

This paper analyses the major challenges affecting Kenya's health sector based on five focus areas namely; governance, financing, human resource \& service delivery, medical supplies and realization of the Right to Health.

\section{Governance}

Governance is a significant component in the realization of the Right to health and within the context of the performance of the health system. The principles of governance enshrined in the Constitution have helped to define the processes for management of public resources, the establishment of institutions required to improve governance, the hierarchy and

122 Kenya Health Policy (2014-2030) at p. 5.

$123 \mathrm{Ibid}$, at p. 26.

124 Leah Kimathi. Challenges of the Devolved Health Sector in Kenya: Teething Problems or Systemic Contradictions? Council for the Development of Social Science Research in Africa. Africa Development, Volume XLII, No. 1, 2017. At p.57. 
frameworks that secure accountability of public officials and the mechanisms that facilitate development and implementation of law and policy. ${ }^{125}$

After promulgation of the new Constitution in 2010, it was envisaged that the transition from centrally managed services to devolved management of the same would be a gradual one. This would ideally, have given time for the establishment of the necessary institutions and capacities at county level. Unfortunately, devolution happened overnight, occasioned by the county governments' desire to consolidate power. ${ }^{126}$ The resultant effect was inconsistency in implementation of law and policy across the various counties, poor staffing, absent or poor coordination between the two levels of government and inefficient management and resource distribution. ${ }^{127}$

The leadership structures at the Ministry of health, which is a national institution, has changed constantly over relatively short timeframe, leading to serious challenges as far as accountability, communication and coordination with relevant stakeholders is concerned. ${ }^{128}$ The situation trickles down to the counties, whose leadership structures are designed to mirror those that are established at national level. Due to the absence of clear functional and uniform management structures to support the delivery of services, county governments also continue to suffer challenges similar to those manifesting at the national level. ${ }^{129}$ This has also led to confusion regarding the roles of the county and national ministry of health, ${ }^{130}$ and lack of capacity among county actors to effectively manage the health sector. ${ }^{131}$ It is also noted that despite the obvious lack of management capacity in the health sector at the county level, targeted capacity building plans have not been put in place by the national Ministry of Health. ${ }^{132}$

In addition to the problems associated with the rushed implementation of health by the county governments, another governance issue that is prominent in the health sector as far as governance is concerned is that of delays and tension in setting up county health frameworks. This particular challenge has been associated with high level political lobbying and canvassing in the appointment of key senior health officials. ${ }^{133}$ Closely connected to this is the clash between vertical programs, occasioned by the reluctance of external donors who are funding programs organized on a vertical basis being reluctant to use devolved struc-

125 Mulaki \& Muchiri, Op cit. at p. 15.

126 L. Kimathi. Challenges of the Devolved Health Sector in Kenya. Ibid, at p. 64.

127 Ibid.

128 Mulaki \& Muchiri, Op cit. at p. 17.

129 Ibid, at p. 18.

130 KEMRI \& Wellcome Trust. Early Experiences and Effects of health Sector Devolution in Kenya. Policy Brief, Feb 2018.

131 KEMRI \& Wellcome Trust, Ibid.

132 Mulaki \& Muchiri, Op cit. at p.23.

133 Ibid. 
tures. This creates the potential for conflict and overlaps between existing vertical health programs and the emerging devolved structures. ${ }^{134}$

The absence of a standard directive or strategy on health management organization at the county level, the lack of a collaborative framework to facilitate coordination, cooperation and accountability continues to plague the governance of the health sector. Essentially, it makes it even more difficult to focus attention to health priorities. ${ }^{135}$

Regulation of the sector continues to present challenges primarily occasioned by an otherwise uncoordinated approach in the introduction of new laws and policies to guide the various aspects of the healthcare system in Kenya. ${ }^{136}$ Regulatory bodies in the sector are numerous, and tend to perform roles that can otherwise be carried out by a single regulatory body. As such, even though the bodies are tasked with improving and ensuring compliance with established standards and requirements, enforcement remains weak, with wanton violation of regulations and punitive measures that are otherwise insufficient in deterring violation of laws and regulations. ${ }^{137}$ Other problems associated with regulator shortcomings include mushrooming unregistered health facilities, increased and unchecked medical malpractice cases, corruption and partial enforcement of existing regulations. ${ }^{138}$

\section{Health Financing \& Resource Mobilisation}

Funding for the health sector in Kenya is sourced from three major sources being, the public sector, private consumers and donor agencies. Consumers remain the largest contributors at $35.9 \%$, followed by the Government and donors at approximately $30 \%$ each. ${ }^{139}$ At County level, the allocation to health stands at less than $5 \%$ of the budget. This a rather dismal performance, especially considering that this paltry amount goes into remuneration of personnel, the purchase of equipment and infrastructure, as well as purchase of drugs. Naturally, the funds are woefully inadequate, and the impact is felt across the entire chain of healthcare delivery. ${ }^{140}$

The Health Policy observes the fairly consistent approach adopted in government expenditure on health as a percentage of total government expenditure. This is noted as ranging between $6-8 \%$ of total expenditure. It is also noted that funding of the health sector continues to flow from sources within the private sector including out-of-pocket spending by households, and an increase in donor resources. Donor contribution to the sector has

134 L. Kimathi, $O p$ cit. at p. 65.

135 Mulaki \& Muchiri, Op cit. at p. 23.

136 The Kenya Health Policy (2014-2030) at p. 20.

137 Mulaki \& Muchiri, Op cit. at p. 20-21.

$138 \mathrm{Ibid}$, at $\mathrm{p} 21$.

139 L. Kimathi, $O p$ cit. at p. 60.

$140 \mathrm{Ibid}$, at p. 61. 
more than doubled to stand at about $35 \% .{ }^{141}$ It is worth noting that Kenya is a signatory to the Abuja Declaration, which mandates African countries to commit to an investment of at least $14 \%$ of the national budget on health.

Efforts to develop health financing strategies to guide resource rationalization and mobilization have been adopted at the national level as part of the reform initiatives targeting the health sector. ${ }^{142}$ The passing of the new Constitution also saw the government introduce a new financing system for the health sector aimed at supplementing county allocations and user fees. This system, carried out through the Health Sector Services Fund (HSSF) operates as a revolving fund that provides direct cash transfers to primary health care facilities including dispensaries and health centers. ${ }^{143}$ Funding amounts are minimal and their disbursement inconsistent, and apart from a lack of clarity concerning the roles of the national and county governments in the management of HSSF funds, there is a general lack of alignment in planning, budgeting and financial management. ${ }^{144}$

Kenya continues to be bogged down by huge debts. This has had a direct impact on the health sector. Revenues remain the largest single source of government funds. With expenditures exceeding income, the net result has been reduced focus on mobilizing resources or otherwise funding the health sector. At the county level, resource mobilization and funding is a preserve of the individual county government, which has the liberty to concentrate resources on priority areas unique to it.

Lopsided financing continues to present long terms sustainability problems and hinders coordinated planning in the sector across both levels of government. Naturally, equity in distribution and delivery of healthcare services is directly affected by the shortcomings connected to financing of the health sector, even as health spending by private consumers if health services continues to skyrocket. ${ }^{145}$

\section{Human Resource \& Delivery of Health Services}

Service delivery is defined by the World Health Organization as how inputs and services are organized and managed to ensure access, quality, safety, and continuity of care across health conditions, different locations and over time. In Kenya, health services are delivered both by public and private sector actors, with the responsibility for delivery of health services resting squarely on the County Governments as set out in earlier sections of this paper.

141 Kenya Health Policy (2014-2030), at p. 12-13.

142 Ibid, at p. 20.

143 L. Kimathi, $O p$ cit. at p. 61.

144 KEMRI \& Wellcome Trust, Op cit.

145 Timothy Okech. Devolution of Public Health Care Services in Kenya and its Implication on Universal Health Coverage. IOSR Journal of Pharmacy, Vol 17, Issue 5 Version 1, May 2017. At p. 9. 
Health care delivery in Kenya is designed to be delivered across six levels. Level 1 comprises Community Health Services (collections of household units staffed by volunteer community health workers); Level 2 - Dispensaries offering primary healthcare services; Level 3- Health Centers offering primary healthcare services including maternity care and nursing homes; Level 4 - Primary Referral Facilities offering referral and curative facilities; Level 5 - Secondary Referral Facilities offering referral and curative facilities; and Level 6 - Tertiary Referral Facilities offering specialized care and training. ${ }^{146}$

Distribution of health facilities across Kenya reveals significant regional disparities in terms of availability of hospitals (level 4-6), health centers and dispensaries (level 2\&3). ${ }^{147}$ Even though strategies have been put in place by the national government for innovative service delivery, application remains limited to only a few areas and programs. ${ }^{148}$

As far as human Resource is concerned, the Health Policy requires an adequate, productive and equitably distributed workforce in the health sector to exist in order for healthcare delivery to be effective. It is therefore impossible to fully assess service delivery in the health sector without examining underlying factors connected to human resource (defined by the Health Policy as the stock of all people engaged in actions whose primary intent is to enhance health). ${ }^{149}$

Several issues mar the human resource component of healthcare delivery in Kenya. Indeed, the Health Policy takes notes of the fact that unionization of health workers and recurrent industrial action present new demands and challenges to the sector. ${ }^{150}$ The failure to apply appropriate strategies, standards and norms to deploy health personnel has resulted in regions perceived as having high socio-economic development being favoured over those that considered marginalized and hard-to-reach. Urban areas therefore tend to have higher proportions of staff at the expense of rural and remote areas. ${ }^{151}$

In 2015 alone, there were more than 15 reported strikes by doctors and other medical personnel, who among other causes, cited understaffing as a primary contributor to industrial action. The lack of adequate personnel in the counties remains a major factor influencing unrest among health workers. ${ }^{152}$ Brain drain also plays a major role in the prevailing understaffing of health facilities in the country, with between $30-40 \%$ of doctors who graduate annually migrating to other jurisdictions offering more favourable employment environments. ${ }^{153}$

146 Kenya Health Policy (2014-2030) at p. 6.

147 Ibid, at p. 15.

$148 \mathrm{Ibid}$, at p. 20.

149 Kenya Health Policy (2014-2030) at. P. 14.

$150 \mathrm{Ibid}$, at p. 17.

$151 \mathrm{Ibid}$, at p. 14.

152 L.Kimathi, $O p$ cit. at p. 59.

153 Ibid. 
Other challenges associated with human resource in the health sector include the absence of structures determining health personnel requirements, absence of funds to recruit health workers, high levels of corruption at the counties in relation to employment processes, fears of job security, particularly at the commencement of devolved governance operations where clarity over Human Resource functions was absent, delayed payment of salaries due to poor coordination and uncertainty of national and county government roles in the transition to devolved governance. Further, lack of clarity concerning career progression, inter-county transfers, salary payments and political interference in staff deployment and recruitment remain rife. ${ }^{154}$

\section{Medical Supplies \& Equipment}

Access to medical products and technologies that are of a high-quality and cost-effective is a necessary ingredient for a well-functioning health system. Ensuring access to essential medicines in Kenya remains a challenge, with shortage of essential medicines and waste of resources on drugs that are of an otherwise low quality remains prevalent. Naturally, this translates into a severely compromised health care system.

Whereas the National Health Policy calls for the establishment of an effective procurement and supply system that leverages public and private investments in order to improve access to health services, the unfortunate truth is that most counties do not have clear procurement structures in place for the purchase and acquisition of medical supplies and equipment. ${ }^{155}$ This is further exacerbated by the insistence of county governments on autonomy, which means that they are unable to collectively take advantage of and benefit from economies of scale. The fragmented procurement exercises only serve to increase costs and create room for corrupt practices. ${ }^{156}$

At the county level, heavy political influence in the procurement of medical supplies and equipment is quite common. ${ }^{157}$ The fact that there have been major disagreements concerning counties sourcing medical supplies from the Kenya Medical Supplies Agency(KEMSA) has only served to widen the existing avenues of corruption, amplify mismanagement and pilfering of public funds and perhaps of all, ensured the perpetual scarcity of drugs at health facilities. ${ }^{158}$ Effective monitoring is necessary if the unscrupulous outsourcing of medical supplies and equipment at the counties is to be curbed with finality.

154 KEMRI \& Wellcome Trust, Op Cit.

155 L. Kimathi, Op cit. at p. 65.

156 Ibid.

157 KEMRi \& Wellcome Trust, Op cit.

158 L. Kimathi, Op cit. at p 62. 


\section{Realisation of the Right to Health}

Even though the legal framework securing the realization of the Right to Health in Kenya is quite robust, several challenges continue to hinder the realization of this right. These have been clearly elucidated in the preceding sections. Progressive realization as a challenge to the full realization of the Right to Health in Kenya is worthy of discussion at this juncture.

In Kenya, the Constitution places an obligation and duty on the State to take legislative, policy and other measures including the setting of standards, to achieve the progressive realization of the right to health. ${ }^{159}$ Progressive realization takes cognizance of the fact that complete realization of economic, social and cultural rights cannot be achieved in a short period of time. That notwithstanding, progressive realization imposes obligations on States to move as expeditiously and effectively as possible towards that goal. In that regard, any measures that are deliberately retrogressive require careful consideration and need to be fully justified by making reference to the totality of rights provided for in the ICESCR and in the context of the full use of the maximum available resources. ${ }^{160}$

As seen below, courts in Kenya have been called upon to determine issues pertaining to the right to health, including within the context of progressive realization. Health is a Socio-Economic Right and the Constitution of Kenya makes such rights justiciable, with courts increasingly addressing various elements connected to the Right to Health. ${ }^{161}$

\section{Enforcing the Right to Health in Kenya: The Role of the Judiciary}

In Kenya, every person has the right to institute court proceedings claiming that a right or fundamental freedom in the Bill of Rights has been denied, violated or infringed, or is threatened. ${ }^{162}$ Such proceedings may be instituted by a person acting in their own interest, ${ }^{163}$ a person acting on behalf of another person who cannot act in their own name, ${ }^{164} \mathrm{a}$ person acting as a member of, or in in the interest of, a group or class of persons, ${ }^{165}$ a person acting in public interest ${ }^{166}$ or an association acting in the interest of one or more of its members. ${ }^{167}$ As such, the High Court has jurisdiction to hear and determine applications for

159 Art. 21(2).

160 Committee on Economic, Social and Cultural Rights (CESCR): General Comment No. 3, 1990.

161 Mapping the Constitutional Provisions on the Right to Health and Mechanisms for Implementation in Kenya. Kenya Legal \& Ethical Issues Network on HIV and AIDS (KELIN) in the Regional Network for Equity in Health in East \& Southern Africa (EQUINET) Study. December, 2018.

162 The Constitution of Kenya, 2010. Art. 22(1).

163 Ibid, Art. 22(2).

164 Ibid, Art. 22(2)(a).

165 Ibid, Art. 22(2)(b).

166 Ibid, Art. 22(2)(c).

167 Ibid, Art, 22(2)(d). 
redress of a denial, violation or infringement of, or threat to, a right or fundamental freedom in the Bill of Rights. ${ }^{168}$

In applying a provision of the Bill of Rights, a court shall - develop the law to the extent that it does not give effect to a right or fundamental freedom; ${ }^{169}$ and adopt the interpretation that most favors the enforcement of a right to fundamental freedom. ${ }^{170}$ Courts are also mandated, when interpreting the Bill of Rights, to promote the values that underlie an open and democratic society based on human dignity, equality, equity and freedom; ${ }^{171}$ and the spirit, purport and objects of the Bill of Rights. ${ }^{172}$ Where there is a claim by the State that it does not have adequate resources to implement the right, the court shall be guided by the principle that; it is the responsibility of the State to show that resources are not available. ${ }^{173}$ Further, the court may not interfere with a decision by a State organ concerning the allocation of available resources, solely on the basis that it would have reached a different conclusion. ${ }^{174}$ Kenyan Courts have over the years addressed themselves on various aspects of the Right to Health based on various claims instituted by different claimants. What follows herein is an overview of what the Courts have rendered in that regard.

In the case of $M A \&$ Another $v$ The Honorable Attorney General \& 4 Others ${ }^{175}$ the petitioners filed a suit against the respondents, who included the City Council of Nairobi, the Minister for Medical Services and the Pumwani Maternal Hospital, for violation of various constitutional rights following the detention of the petitioners at the Pumwani Maternity Hospital following their inability to pay maternity fees. They were detained in deplorable conditions until such time as their spouses and family were able to raise sufficient funds to pay for their fees, following which they were discharged from the facility. The case raised many issues including the right to health, the right to dignity, liberty and to free from cruel, inhuman and degrading treatment as well as unlawful detention.

The Court ruled that the detention of the Petitioners by the $5^{\text {th }}$ Respondent (Pumwani Maternity Hospital) was both arbitrary and unlawful, which act in a health care facility is a violation of the constitutional and human rights standards under the Constitution, and international conventions and treaties that Kenya is party to. The Court also declared the conduct of the $5^{\text {th }}$ Respondent against the Petitioners before and during their detention constituted an infringement of the Petitioners' fundamental rights; specifically, the right to equality and freedom from discrimination; ${ }^{176}$ the inherent dignity and the right to have that

168 Ibid, Art. 23(1).

169 Constitution of Kenya, 2010. Art. 20(3)(a).

170 Ibid, Art. 20(3)(b).

171 Ibid, Art. 20(4)(a).

172 Ibid, Art. 20(4)(b).

173 Ibid, Art. 20(5)(a).

174 Ibid, Art. 20(5)(c).

175 Petition 562 of 2012, [2016] eKLR.

176 The Constitution of Kenya, 2010. Art. 27(4). 
dignity respected and protected; ${ }^{177}$ the right to freedom and security of the person; ${ }^{178}$ the right to freedom of movement and residence; ${ }^{179}$ the right to economic and social rights including the right to the highest attainable standard of health, the right not be denied emergency medical treatments and the provision of appropriate social security to persons who are unable to support themselves and their dependents; ${ }^{180}$ the protection of the family unit by the State ${ }^{181}$ and the right of every child to be protected from abuse, neglect...all forms of violence, inhuman treatment and punishment. ${ }^{182}$

In addition to awarding damages to the tune of about 15000USD and 5000USD to the respective Petitioners, the Court declared that the Kenyan Government must take the necessary steps to protect all patients from arbitrary detention in health care facilities, including enacting laws and policies and taking affirmative steps to prevent future violations. The City Council of Nairobi, the Minister for Medical Services and Pumwani Maternity Hospital, $\left(3^{\text {rd }}-5^{\text {th }}\right.$ Respondents) were also directed by the Court to develop clear guidelines and procedure for implementing the waiver system in all public hospitals, and to take necessary administrative, legislative, and policy measures to eradicate the practice of detaining patients who cannot pay their medical bills.

In JOO VAG \& 6 Others $^{183}$ the Petitioner filed a Constitutional petition in a bid to enforce various rights. The Petitioner was a woman from a low-income background, who, while in need of maternal health care visited Bungoma County Referral Hospital, in a health facility that ought to provide free maternal health care following a Presidential directive issued on $1^{\text {st }}$ June, 2013. In finding for the Petitioner and awarding damages to the tune of approximately 25000USD, the Court made reference to the Constitution, ${ }^{184}$ the ICES$\mathrm{CR}^{185}$ and the African Charter on Human and People's Rights, ${ }^{186}$ acknowledging that these provisions speak to the right of health care, which encompasses proper treatment at hospital and availability of necessary equipment, facilities and medication. The Court found that the Petitioner received none of the above, and requiring the Petitioner and other poor women to purchase basic necessities in a public facility where health care is anchored on the constitution and where a presidential directive was specific on the provision of free maternal care is nothing short of violation of a basic right.

177 Ibid, Art. 28.

178 The Constitution of Kenya, 2010. Art. 29(a-d, f).

179 Ibid, Art. 39(1,3).

180 Ibid, Art. 43(1(a), 2,3).

181 Ibid, Art. 45(1).

182 Ibid, Art. 53(d).

183 Petition 5 of 2014, [2018] eKLR.

184 Art. 43(1)(a).

185 Art. 12(1).

186 Art. 16. 
In relation to the right to dignity. and the right not to be treated or punished in a cruel, inhuman or degrading manner, the Court ruled that the action of the nurses of the $5^{\text {th }} \mathrm{Re}$ spondent denied, derogated and demeaned the Petitioners worth, thus infringing on her dignity as a woman and as a member of the human race. The Court found the National and County governments as not having devoted adequate resources to healthcare services, nor put in place effective measures to implement, monitor and provide minimum acceptable standards of healthcare, thus violating the Constitution and international instruments acceded to by Kenya as a country.

The neglect the Petitioner suffered was found as having resulted from the National and County governments failure to ensure healthcare services were affordable and of good quality. The failure to the governments to develop and/or implement policy guidelines on healthcare denied the Petitioner her right to basic healthcare. The failure by the governments to implement and/or monitor the standards of free maternal health care was what resulted in the mistreatment of the Petitioner and the subsequent violation of her right to dignity.

The Court discussed progressive realization of the right to health in light of various international instruments in Mathew Okwanda v Minister of Health \& Medical Services \& 3 Others ${ }^{187}$ which was filed by an elderly petitioner suffering from diabetes mellitus and lacking the financial means to manage his illness due the cost of medical care. The Court emphasized the importance of socio-economic rights, as well as the need to address issues pertaining to poverty, ignorance, unemployment and disease, as failure to do so would result in an undermining of the Constitution. The Luco Njagi \& 21 Others $v$ The Ministry of Health, Kenyatta National Hospital and the National Hospital Insurance Fund, ${ }^{188}$ the Petitioners sought mandatory orders to compel the Ministry of Health to meet the cost of medical dialysis or to subsidies the cost of medical dialysis at private facilities named in the petition, at the rate at which the petitioners would have accessed treatment at the Kenyatta National Hospital. The $3^{\text {rd }}$ Respondent does not offer covers for the petitioners' condition.

The Court made reference to the South African case of Soobramoney $v$ Minister of Health Kwa Zulu Natal 1997 (12) BCLR 1696 where it stated that

"...A court will be slow to interfere with rational decisions taken in good faith by the political organs and medical authorities whose responsibility it is to deal with such matters. [30] Although the problem of scarce resources is particularly acute in South Africa this is not a peculiarly South African problem. It is a problem which hospital administrators and doctors have had to confront in other parts of the world, and in which they have had to take similar decisions. In his judgment in this case Combrinck J refers to decisions of the English courts in which it has been held to be undesirable for a court to make an order as to how scarce medical resources should be applied, and to the danger of making any order that the resources be used for a parti- 
cular patient, which might have the effect of denying those resources to other patients to whom they might more advantageously be devoted."

The Court opined that the sad and inescapable truth about our (Kenyan) circumstances is that there are countless other people facing similarly dire medical situations which compete with those of the petitioners. If the court were to order that those who need renal dialysis should be treated at the State's expense in private institutions, why not for those with equally serious illness for whom access to health care in public institutions is limited? It was considered to be outside the Court's province. Despite acknowledging the difficult and lifethreatening situation the petitioners were in, the Court found itself unable to find a violation of the rights of the petitioner and therefore unable to issue any of the orders that they sought.

It was the considered finding of the Court that they are not institutionally equipped to make the wide-ranging factual and political enquiries necessary for determining what the minimum-core standards should be, nor for deciding how public revenues should effectively be spent, especially considering the many pressing demands on the public purse. The final outcome was a finding that the measures taken by the Respondents to ensure access to hemodialysis by the Petitioner were reasonable in the circumstances, resulting in a dismissal of the suit with no order as to costs.

\section{E. KEY RECOMMENDATIONS}

Having identified discussed the various challenges affecting the health sector in Kenya, the following measures are recommended. For Governance issues, it is recommended that the Ministry of Health develop, in conjunction with stakeholders at national and county levels, a county management model that will guarantee uniformity in management of the health sector at the County level. In addition, it is necessary to implement targeted capacity building with health service providers and actors in line with the principal legislation governing the sector, including Civil Society Organisations and the general public. This would go a long way in strengthening public participation and citizen engagement in decision-making processes related to the health sector. It is also recommended that the national government streamline regulatory functions in order to reduce duplicity and overlap in roles and functions amongst the numerous regulatory bodies in existence. There should be clarity of roles between national and county governments especially with regard to control of facilities, management, budgets and funding.

With regard to financing and resource mobilization, it is recommended that County Governments be empowered on resource mobilization through collection of locally generated revenues. In addition, targeted capacity building should be undertaken in order to strengthen the ability of the County Governments to adequately plan, budget for and manage finances for the health sector. Innovative strategies for the harnessing of resources for the health sector should be put in place, both for the national and the county governments. Allocation of resources should be target-oriented and responsive to the individual health needs 
of different counties. The National Hospital Insurance Fund, being the national health insurer, should undergo legislative and institutional reform to ensure that it plays its role adequately.

Service delivery and human resource should also benefit from deliberate measures to improve work conditions and health infrastructure. It is necessary for the two levels of government to invest more in order to improve the overall delivery capacity of health facilities. This calls for adequate budgetary allocation to ensure that scientifically appropriate equipment and high quality medicines are sourced. Procurement procedures should also be harmonized and made transparent, and where possible, avenues on ways to benefit from economies of scale should be fully explored. With regard to human resource, there is need to harmonise the relationship between private and public health service providers at both levels of government. Further, there should be clarity of roles between the County Directorate for Health, the Public Service Board and the Ministry of Health as far as training, transfers, job security and career progression is concerned. Training of health care providers should also be prioritized and undertaken as a matter of urgency within the counties. Employee retention should be prioritized, as should the creation of conducive work environments for health workers.

\section{F. CONCLUSION AND WAY FORWARD}

In conclusion, the evolution of health care governance in Kenya has made significant strides forward, even though a lot needs to be addressed and adjusted to ensure that users of health services benefit from and attain the highest possible standard of health as envisaged in Constitution of Kenya and in the National Health Policy. Even though devolution is relatively established, these areas remain clouded with uncertainty and continue to experience teething problems, a scenario which would definitely benefit from additional research. Areas for further research include County Procurement Processes, Labour Relations as well as Leadership \& Management frameworks at the county level. 